A N N A LES

\begin{tabular}{l} 
UNIVERSITATIS MARIAE CURIE-SKŁODOWSK A \\
LUBLIN - POLONIA \\
VOL. XV, 1 \\
\hline
\end{tabular}

Instytut Muzykologii Uniwersytetu im. Adama Mickiewicza w Poznaniu

\title{
Magdalena Walter-Mazur
}

\section{Zapominany instrument, zapomniana praktyka. Tromba marina $w$ klasztornym muzykowaniu $w$ XVIII wieku}

The Forgotten Instrument and Forgotten Practice. Tromba marina in Music-Making in Monasteries in the 18th Century

Tromba marina, zwana także tuba marina, tuba maritima, Trumscheit ${ }^{1}, M a-$ rientrompette, Nonnengeige, jest instrumentem, który powstał z przekształcenia monochordu. Posiada bardzo wydłużony, wąski korpus i jedną strunę. Jest ona skracana w manierze flażoletowej, przez co instrument wydobywa alikwoty tonu podstawowego. Pierwszy opis takiego instrumentu, określonego jako tubalcanna, pojawia się w Liber viginti artium Paulusa Paulirinusa (ok. 1460)². Zachowane wczesne przedstawienia ukazują go z jednej strony jako atrybut „,anielski” - prawdopodobnie przez utożsamianie go z jakimś instrumentem biblijnym, z drugiej jako akompaniujący „tańcom śmierci”. Ów drugi sposób przedstawiania wiąże

\footnotetext{
${ }^{1}$ Silke Berdux uważa, że nazwa Trumscheit (oraz pochodne od niej - Drumscheit, Trummelscheit) przynależy do instrumentu w jego wcześniejszej formie i była używana w XV i XVI wieku (S. Berdux, E. Tremmel, Trumscheit/Tromba marina, [w:] Die Musik in Geschichte und Gegenwart, red. L. Finscher, Sachteil, t. 8, Kassel-Bazylea 1998, szp. 972). W artykule dołączonym do płyty Musik aus Schweizer Kloestern mit Tromba Marina Berdux sugeruje wręcz, że powinno się Trumscheit i tromba marina traktować jako dwa różne instrumenty. (http://www.arcimboldo.ch/ensemble/ arcimboldo_projekte_Musik_aus_Schweizer_Kloestern.htm\#Besetzung [data dostępu: 06.02.2017].

${ }^{2}$ Fol. 162, cyt. [za:] Berdux, Tremmel, op. cit., szp. 975.
} 
się zapewne z średniowieczną praktyką wykorzystywania tromba marina w muzyce świeckiej przez wędrownych szpilmanów i kojarzenie go z zabawą, tańcem i śpiewem.

W swoim traktacie z 1511 roku Sebastian Virdung zaliczył Trumscheit do instrumentów bezużytecznych, co było powtarzane także przez niektórych późniejszych teoretyków³. Bardziej przychylną opinię znaleźć można u Glareana, który z autopsji opisał instrument o długości około $150 \mathrm{~cm}$, wydobywający osiem tonów harmonicznych. $\mathrm{Z}$ racji braku możliwości wykorzystania diatoniki jednak i jemu nie wydał się on interesujący. Dopiero Michael Praetorius, opisując w liście do Marina Mersenne’a instrument z własnej kolekcji o długości około $210 \mathrm{~cm}$, mający oprócz struny skracanej trzy struny sympatetyczne, stwierdza, iż brzmi on ,jakby cztery trąbki jednocześnie grały i pięknie stroiły"4.

W pierwszej połowie XVII wieku instrument ulega przekształceniom, zmienia się sposób trzymania: z pozycji wzniesionej ku górze z podparciem na piersi na opartą na podłożu i orientowaną ukośnie w stosunku do ciała grającego. Wzrasta długość korpusu, przez co możliwe jest wydobycie większej liczby tonów harmonicznych, także tych tworzących szereg diatoniczny. Niekiedy dodana jest druga struna na korpusie lub kilka nawet strun wewnątrz, które pełnią rolę strun rezonujących. Kluczową dla „trąbkowego” brzmienia instrumentu jest kwestia mostka. W większości zachowanych instrumentów jest on zamocowany tylko z jednej strony, podczas gdy druga strona pod wpływem drgań struny uderza swobodnie o pudło rezonansowe, nadając dźwiękowi ów specyficzny lekki warkot. Na podstawie dawniejszej ikonografii trudno stwierdzić, czy taki sposób mocowania mostka był od początku charakterystyczny dla tromba marina.

W profesjonalnej praktyce muzycznej instrument ten raczej się nie zadomowił, choć niewątpliwie miał swoje „pięć minut” w muzyce francuskiej około połowy XVII wieku. Wtedy też popularyzuje się nazwa tromba marina, która ma różne fantastyczne i nikogo nieprzekonujące etymologie 5 . W 1660 roku Lully

${ }^{3}$ Autorzy artykułu w Die Musik in Geschichte und Gegenwart uważają, iż opinia Virdunga dotyczyła przede wszystkim użyteczności Trumscheitu w kształceniu muzycznym, a nie w ogóle w praktyce muzycznej (ibid., szp. 976).

${ }^{4}$ Correspondance du P. Marin Mersenne, religieux minime: publiée et annotée par Cornelis de Waard; avec la collaboration de Armand Beaulieu; édition entreprise sur l'initiative de madame Paul Tannery et continuée par le C.N.R.S, Éditions du Centre national de la recherche scientifique, t. 4, Paryż 1955, s. 59, cyt. [za:] ibid., szp. 977.

${ }^{5}$ Nazwę tę odnoszono m.in. do rzekomego wykorzystywania tego instrumentu przez marynarzy lub do jego użytkowania w klasztorach jako „trąby maryjnej”. Zob.: C. Adkins, A. Dickinson, A Trumpet by any other Name: A History of the Trumpet Marine, t. 1, Buren 1991, s. 24-30. Cytowana praca składa sie z dwóch tomów, z których pierwszy mieści monografię instrumentu, drugi zaś katalog 188 zachowanych trombae marinae. 
wykorzystał trombae marinae w ustępach baletowych opery Cavallego Xerxes, wystawionej z okazji królewskiego ślubu ${ }^{6}$, w 1661 roku zaś na dworze Ludwika XIV powołano zespół składający się z pięciu muzyków grających na krumhornach i trombae marinae, który istniał jeszcze sto lat później, choć nie wiadomo, czy w XVIII wieku stanowisko w tym zespole nie było rodzajem synekury?

Jedynym znanym z nazwiska wirtuozem tego instrumentu był Jean Baptiste Prin (ok. 1669-po 1742), Francuz urodzony w Anglii, tancerz, aktor i kompozytor. Prawdopodobnie to właśnie jego ojciec był Monsieur Prinem, którego koncert odnotował w swoim dzienniku Samuel Pepys pod datą 24 października 1667 roku. Jego gra na tromba marina wywarła wielkie wrażenie na angielskim pamiętnikarzu. Ojciec był też najpewniej nauczycielem Jeana Baptiste'a, który od 1698 działał w Paryżu jako aktor i muzyk grający na tromba marina, a następnie przeniósł się do Lyonu, gdzie kontynuował karierę instrumentalisty oraz zajmował się nauczaniem ${ }^{8}$. W 1742 roku, świadom braku zainteresowania grą na tym specyficznym instrumencie wśród współczesnych, przekazał Akademii w Lionie zbiór przeznaczonych nań 216 utworów oraz ułożony przez siebie traktat Memoire sur la trompette marine, w którym zawarł wyznanie-epitafium: „kochałem czule ten instrument i z żalem widzę, jak umiera on wraz ze mną"”.

Tromba marina zyskała szansę pozostania w zbiorowej pamięci szczególnie dzięki dziełom Memlinga i Moliera. Ten pierwszy w swoim słynnym tryptyku ukazał muzykujące anioły, z których drugi z lewego skrzydła gra na XV-wiecznej postaci tromba marina - mniejszej niż późniejsza i trzymanej z oparciem na piersi ${ }^{10}$. Z kolei Molierowski Pan Jourdain, w rozmowie z nauczycielem muzy$\mathrm{ki}$, domagał się podczas przygotowań do organizowanego w jego domu koncertu dołączenia tromba marina do zespołu złożonego z głosów wokalnych, grupy continuo i dwojga skrzypiec ${ }^{11}$ :

\footnotetext{
${ }^{6}$ Ibid., s. 50.

${ }^{7}$ Cromorne et Trompette Marine des Ecuries du Roy. W sumie na stanowiskach w tym zespole zatrudnionych było czterdziestu sześciu muzyków. Zob.: ibid., s. 51.

${ }^{8}$ C. Adkins, Prin, Jean-Baptiste, [w:] The New Grove Dictionary of Music and Musicians, t. 20, red. S. Sadie, Londyn 2001-2002, s. 323.

${ }^{9}$ Cyt. [za:] Adkins, Dickinson, op. cit., t. 1, s. 56. Ów traktat Prina, poświęcony jego ukochanemu instrumentowi, został wydany w języku oryginalnym i w tłumaczeniu na język angielski w Dodatku do monografii Adkinsa i Dickinson (ibid., t. 1, s. 195-222).

${ }^{10}$ Hans Memling, Muzykujące Anioły (1470) - tryptyk olejny na desce, powstały dla kościoła Santa Maria La Real w Naher w Kastylii. Uważa się, iż malarz w swoim przedstawieniu nawiązał do bogatego życia muzycznego Brugii w II połowie XV wieku. Obraz przechowywany jest w Królewskim Muzeum Sztuk Pięknych w Antwerpii.

${ }^{11}$ Fragment dramatu cytuję w języku oryginału, ponieważ w polskim przekładzie Tadeusz Boy-Żeleński zastąpił interesujący nas instrument kobzą, obawiając się zapewne, iż publiczność nie
} 
"MAÎTRE DE MUSIQUE.— - [...] Il vous faudra trois voix, un dessus, une haute-contre, et une basse, qui seront accompagnées d'une basse de viole, d'un théorbe, et d'un clavecin pour les basses continues, avec deux dessus de violon pour jouer les ritornelles.

MONSIEUR JOURDAIN. - Il y faudra mettre aussi une trompette marine. La trompette marine est un instrument qui me plait, et qui est harmonieux" ${ }^{\prime 2}$.

Przytaczając ten cytat, Cecil Adkins opatruje go komentarzem zaczerpniętym z Les grotesques de la musique Hectora Berlioza, wydanym po raz pierwszy w 1859 roku. Berlioz uważał, że wymiana zdań na temat obsady zespołu muzycznego mogła budzić u spektatorów salwy śmiechu, ponieważ XIX-wieczna publiczność nie wiedziała, o jaki instrument $w$ istocie chodzi. Prawdopodobnie wyobrażała go sobie - sugerując się nazwą - jako jakiś instrument dęty o potwornym brzmieniu, przez co uwaga Pana Jourdain stawała się absurdalna, a nie tylko naiwna ${ }^{13}$. Współcześni Moliera z pewnością zaś wiedzieli, o jakim instrumencie mowa. Trudno zatem dociec, jakiego efektu spodziewał się Molier, wkładając w usta usilnie aspirującego do wyższych sfer bohatera zdanie na temat tromba marina. Nie bez znaczenia pozostaje fakt, że dramatopisarz stworzył Mieszczanina szlachcicem na zamówienie króla Ludwika XIV, który, jak już wiemy, posiadał na swoim dworze zespół wykorzystujący te oryginalne chordofony. Być może też zabawne mogło się wydać określenie tromba marina mianem instrumentu harmonijnego - jego czysty harmoniczny strój nie współbrzmiał idealnie z nierównomiernie temperowanym strojem innych instrumentów zespołu, zwłaszcza jeśli muzyk na nim grający nie był mistrzem w swej sztuce. A może chodziło o wizualny dysonans między skromnym i eleganckim zespołem a pokaźnym, dwumetrowym „kawałem drewna”?

Wspomniany wyżej pierwszy i ostatni znany wirtuoz i apologeta tego zapomnianego przez historię instrumentu, Jean Baptiste Prin, w swoim traktacie-pamiętniku spisanym w 1742 roku odpowiada Molierowi z widoczną urazą, że

wiedziałaby, o jaki instrument chodzi, i nie uchwyciła zamierzonego efektu komicznego, polegającego - zdaniem tłumacza - na niedorzeczności tej propozycji:

„NAUCZYCIEL MUZYKI: [...] Potrzeba panu trzech głosów: sopran, tenor i bas; do akompaniamentu zaś altówka, teorban, klawicymbał dla basso continuo i dwoje skrzypiec do ritorneli.

PAN JOURDAIN: Trzeba by także postarać się o kobzę. Kobza to mój ulubiony instrument, nadzwyczaj melodyjny", https://wolnelektury.pl/media/book/pdf/mieszczanin-szlachcicem.pdf [data dostępu: 16.01.2017].

${ }^{12}$ Moliere, właśc. Jean Baptiste Poquelin, Le Bourgeois Gentilhomme (1670), http://www.toutmoliere.net/IMG/pdf/bourgeois_gentilhomme.pdf [data dostępu: 16.01.2017].

${ }^{13}$ Adkins, Dickinson, op. cit., s. 15-16. 
gdyby na tromba marina grano tak dobrze, jak grał sam Prin, instrument nie zostałby porzucony, i jeśli Pan Molier słyszałby autora grającego z najlepszymi instrumentalistami Francji, zrozumiałby, iż sam był «le bourgeois gentilhomme» wyśmiewając go"14.

Czytelnik zastanawia się zapewne, dlaczego rozwodzę się tak nad owym Molierowskim dialogiem. Otóż taką właśnie praktykę wykorzystywania tromba marina $\mathrm{w}$ wykonaniach wokalno-instrumentalnych, jaką zaproponował nieokrzesany Pan Jourdain, spotykamy w żeńskich ośrodkach klasztornych, jednak nie tylko w XVII, lecz także w XVIII, a nawet XIX wieku.

Spośród wielu różnych nazw ${ }^{15}$, jakie nadawano temu kuriozalnemu instrumentowi, najpóźniejsze historycznie, bo pochodzące dopiero z XIX wieku, są nazwy wskazujące na używanie go przez zakonnice ${ }^{16}$. Są to trzy określenia w języku niemieckim bazujące na złożeniach Nonne- (zakonnica) z dodaną nazwą instrumentu lub określeniem jego funkcji w zespole: Nonnengeige, Nonnentrompette, Nonnenbas. Ich istnienie dowodziłoby, iż na niemieckim obszarze językowym jeszcze w tym stuleciu zakonnice posługiwały się w swojej praktyce muzycznej interesującym nas instrumentem ${ }^{17}$.

Adkins i Dickinson - jako pierwsi - w swojej znakomitej monografii postanowili odpowiedzieć na pytanie o to, czy, gdzie i w jaki sposób zakonnice używały w swej praktyce muzycznej owych szczególnych instrumentów. Swoje konstatacje oparli na badaniu zachowanych źródeł narracyjnych, muzykaliów, ale przede wszystkim na samych zachowanych instrumentach. Spośród 83 trombae marinae, których proweniencja jest znana, aż 35 pochodzi bowiem z klasztorów ${ }^{18}$, w tym 31 z klasztorów żeńskich.

${ }^{14}$ Jean Baptiste Prin, Memoire J.-B. Prin, MS. (Mo,133670) City Library at Lyon, Memoire sur la Trompette Marine, 1742, cyt. [za:] F. Galpin, Monsieur Prin and His Trumpet Marine, "Music and Letters" 14: 1933, nr 1, s. 28. Zob. też: D. Newton, Tromba marina. A study in organology, 1978/2002, http://www.oriscus.com/mi/tm/index.htm [data dostępu: 18.01.2017].

${ }^{15}$ Do ich wielości nawiązuje tytuł cytowanej już monografii poświęconej tromba marina autorstwa Cecila Adkinsa i Alis Dickinson (op. cit.). Autorzy wyliczają trzy grupy etymologiczne nazw instrumentu: 1. z przedrostkiem Trum- lub drum- (np. Trumscheit) - 23 formy; 2. z członem Maria lub marina (np. tromba marina, tuba marina, w języku polskim tubmaryna) - 41 form; 3 . z przedrostkiem Nonnen -3 formy: Nonnengeige, Nonnenbas, Nonnentrompette.

${ }^{16}$ Ibid., s. 31-32.

${ }^{17}$ J. Rühlmann podaje, że jeszcze w 1880 roku zakonnice z St. Marienthal w Saksonii wykonywały intrady w kwartecie trombae marinae wraz z kotłami (Bogeninstrumente, s. 30, cyt. [za:] ibid., s. 31).

${ }^{18}$ Adkins i Dickinson zaznaczają, iż zapewne także wiele z zachowanych bez proweniencji eksponatów muzealnych może pochodzić z klasztorów (ibid., s. 67). 
Zastanawiając się nad sposobami wykorzystania tromba marina i analizując dostępną literaturę, Adkins i Dickinson doszli do wniosku, że instrument mógł pełnić cztery różne funkcje: być wykorzystywany w praktyce śpiewu chorałowego, co jest najsłabiej udokumentowane ${ }^{19}$, służyć jako instrument fundamentalny realizujący wraz z organami basso continuo lub jako substytut trąbek w obsadach wokalno-instrumentalnych, ponadto zespół złożony z trzech lub czterech trombae marinae $\mathrm{z}$ towarzyszeniem kotłów mógł wykonywać fanfary.

Jakie zatem możliwości techniczne posiadał ów tajemniczy instrument, przez jednych XVI- i XVII-wiecznych muzyków uważany za bezużyteczny i okropnie brzmiący, przez innych zaś aprobowany i doceniany, a w następnych wiekach zapomniany przez profesjonalnych instrumentalistów i używany już tylko za murami klasztorów? Dwight Newton opisuje jedyny znany mu współczesny eksperyment mający na celu określenie możliwości tromba marina. Został on przeprowadzony przez Nicholasa Bessaraboffa, autora katalogu zbioru instrumentów Boston Museum of Fine Arts, z wykorzystaniem instrumentu pochodzącego z dawnej kolekcji Francisa Williama Galpina ${ }^{20}$. Wydano następującą opinię:

„Kiedy mostek umieszczony jest w odpowiednim miejscu, a napięcie struny jest wyważone w stosunku do mostka, dźwięk staje się zadziwiająco czysty i głośny; brzmienie staje się tak podobne do barwy trąbki, a cały efekt tak zaskakujący, że trzeba to usłyszeć, aby uwierzyć. Dźwięki możliwe do zagrania na naszej tromba marina i mające „trąbkową” jakość brzmienia, na strunie nastrojonej do $C$ są następujące: $C, c, g, c^{1}, e^{1}, g^{1}, b^{1}$, $c^{2}, d^{2}, e^{2}, f^{2}, g^{2}$. Pusta struna brzmi z warczącym rezonansem; dźwięk $b^{1}$, podobnie jak na trąbce czy rogu, nie stroi w stosunku do skali temperowanej; bezpieczna granica skali na instrumencie z naszego Muzeum to $c^{2}$ : ponad tym punkty skracania struny leżą bardzo blisko siebie, a dźwięk traci swą siłę i trąbkową jakość”'²1.

${ }^{19}$ Raczej jako burdon (ibid., s. 68). Adkins i Dickinson przytaczają także opinię zawartą w pracy Serafina Arnolda, zgodnie z którą franciszkanki z Altdorf zastępowały głosy męskie, grając na tromba marina. Jest to o tyle dziwne, że instrument ten ma ograniczone możliwości melodyczne, a diatoniczną skalę można na nim uzyskać dopiero w oktawie dwukreślnej. S. Arnold, Kapuzinnenkloster Altdorf, Altdorf 1977, s. 45, cyt. [za:] ibid., s. 69.

${ }^{20}$ Francis William Galpin (1858-1945) był badaczem i kolekcjonerem instrumentów muzycznych, duchownym anglikańskim, autorem pierwszych fundamentalnych prac z zakresu instrumentologii. Jego kolekcję, liczącą ponad 500 instrumentów, przekazano do Museum of Fine Arts w Bostonie. W rok po jego śmierci powstało Galpin Society kontunuujące badania nad dawnymi instrumentami. Zob.: R. Williamson, Galpin, Francis William, [w:] The New Grove Dictionary of Music and Musicians, t. 9, red. S. Sadie, Londyn 2001-2002, s. 482-483.

21 "When the bridge is properly placed and the string tension is delicately balanced with respect to the mass of the bridge, the sounds become surprisingly clear and loud; the timbre becomes so si- 


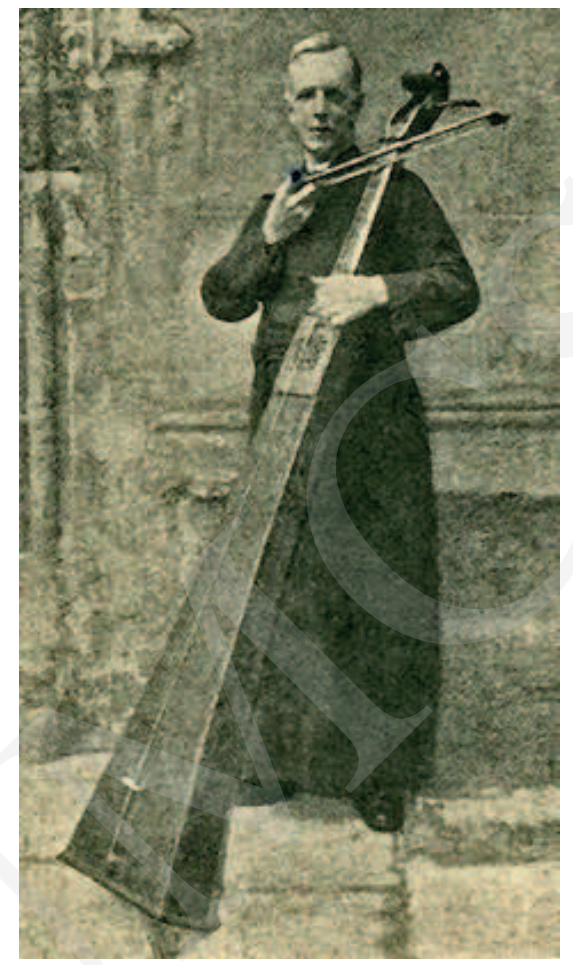

Ilustracja 1. Francis William Galpin grający na swojej tromba marina, zdjęcie ze strony http://www.galpinsociety.org/history.htm.

Newton dodaje, iż prawdopodobnie instrument Messieure Prina był większy i posiadał dłuższą strunę, co sprawiało, że punkty skracania struny dla najwyższych harmonicznych leżały dalej od siebie, co mogło ułatwiać ich wykorzystanie i poprawiać brzmienie. Wydaje się więc, iż nie ma powodu wątpić w sensowność używania tego instrumentu przez zakonnice zarówno w wykonaniach utworów wokalno-instrumentalnych, jak i fanfar, skoro jego możliwości dorównywały atutom trąbki naturalnej.

Adkins i Dickinson wskazali 29 ośrodków zakonnych (w tym 26 klasztorów żeńskich), w których kultywowano grę na Nonnengeige, konstatując, iż była to

milar to that of the trumpet and the whole effect is so startling that it must be heard to be believed. The tones playable on our tromba marina and having an acceptable «trumpety» quality of tone, with the string tuned to C, are as follows: C, c, g, c', e', g' (b' flat), c', (d", e', f', g"). The open string sounds with a snarling resonance; the b' flat, as on the trumpet or horn, is out of tune with the tempered scales; the safe limit on the Museum's instrument is c": above that the nodal points come too close together and the sound loses its force and its trumpety quality". N. Bessaraboff, Ancient European Musical Instruments, Nowy Jork 1941, s. 319, cyt. [za:] Newton, Tromba marina ..., http:// www.oriscus.com/mi/tm/index.htm [data dostępu: 18.01.2017]. 
specjalność zakonnic (w mniejszym stopniu zakonników) z Europy Środkowej22. Do wymienionych przez tych autorów ośrodków - dzięki najnowszym badaniom - jesteśmy w stanie obecnie dodać kolejne klasztory: augustianek św. Jakuba auf der Hülben w Wiedniu ${ }^{23}$, serwitek w Insbrucku ${ }^{24}$ oraz trzy kolejne w niemieckojęzycznej części Szwajcariii ${ }^{25}$. Co więcej, możemy także poszerzyć geograficzny obszar występowania w klasztorach praktyki gry na tromba marina w kierunku północno-wschodnim ${ }^{26}$. Mamy bowiem dowody kultywowania jej w klasztorach benedyktynek z Sandomierza i Lwowa ${ }^{27}$ oraz klarysek ze Starego Sącza ${ }^{28}$, a także w bursie jezuickiej w Krakowie ${ }^{29}$. Dodatkowo można przypuszczać, iż instrumenty takie posiadał także klasztor Cystersów w Obrze ${ }^{30}$.

${ }^{22}$ Rzeczywiście warto zwrócić uwagę na fakt, iż brak jest informacji na temat wykorzystywania trombae marinae przez zakonnice włoskie, znane z szerokiego kultywowania muzyki. Wiadomo natomiast, że instrumenty te były w posiadaniu dwóch z czterech weneckich Ospedali: della Pieta, znanego z działalności w nim Vivaldiego, oraz dei Mendicanti. Zob.: J. L. Baldauf-Berdes, Women Musicians of Venice. Musical Foundations. 1525-1855, Oksford 1993, s. 170-171.

${ }^{23}$ J. K. Page, Convent Music and Politics in Eighteenth-Century Vienna, Cambridge 2014, s. $42,67$.

${ }^{24}$ L. M. Koldau, Frauen - Musik - Kultur. Ein Handbuch zum deutschen Sprachgebiet der Fruehen Neuzeit, Kolonia 2005, s. 868. Tamtejsze zakonnice grały zresztą także na „prawdziwych” trąbkach.

${ }^{25}$ S. Berdux, 'Tromben mit einer Seite bespannet'. Zur Geschichte der Trumscheit und Tromba Marina, http://www.arcimboldo.ch/ensemble/arcimboldo_projekte_Musik_aus_Schweizer_Kloestern.htm [data dostępu: 09.02.2017].

${ }^{26}$ Muzeum Instrumentów Muzycznych (Oddział Muzeum Narodowego) w Poznaniu posiada dwie trombae marinae. Są to prawdopodobnie jedyne egzemplarze znajdujące się w naszym kraju (ujęte w katalogu C. Adkinsa i A. Dickinson): 1. MNP I 78, pochodzi z Łużyc z XVIII wieku, przekazana do Muzeum z okolic Chodzieży, długość $182 \mathrm{~cm}$; 2. MNP I 79, datowana na XVIII/XIX wiek, dar Muzeum Miejskiego w Zielonej Górze, instrument zbudowany na korpusie rezonansowym harfy, posiada karteczkę ze słabo czytelnym napisem w języku niemieckim, długość $147 \mathrm{~cm}$. Za podanie powyższych informacji składam serdeczne podziękowanie Patrykowi Frankowskiemu, kierownikowi Muzeum Instrumentów Muzycznych w Poznaniu.

${ }^{27}$ M. Walter-Mazur, Figura i fraktem. Kultura muzyczna polskich benedyktynek w XVII $i$ XVIII wieku, Poznań 2014, s. 160.

${ }^{28}$ H. Cempura, Kultura muzyczna klasztoru pp. Klarysek w Starym Saczu w latach 1700-1782, Tarnów 2009, s. 56. Cempura przypuszczał nota bene, że chodziło o tubę - instrument dęty.

${ }^{29} \mathrm{~W}$ rękopisie 2431 Biblioteki Jagiellońskiej Liber Resignationum Bursae Regiae musicorum Colegii Craco. Soc. Iesu [...] Anno Domini 1737 (cyt. [za:] A. Mądry, Barok. Część druga 1697-1795, Historia muzyki polskiej, t. 3, Warszawa 2013, s. 347-351) znajdujemy m.in. inwentarze instrumentów z lat 1686, 1712, 1714, 1715 i 1764/1765. Wśród instrumentów chórowych kolegium jezuickiego figurują: w roku 1686 ,tubae marinae 4”, w 1712 „tuba marina 1”, w 1714 instrument nie jest wymieniony, w 1715 „Tuba marina zła” i w 1764/1765 „Tuby maryny 2”. Można przypuszczać, że po roku 1715 kupiono nowe instrumenty.

${ }^{30}$ Wykaz instrumentów sporządzony w 1839 roku wylicza obok trzech „trąb starych do użytku niezdatnych” dwa „kije ad modum tuby”, które, jak przypuszczam, mogły być egzemplarzami 
Pobrane z czasopisma Annales L - Artes http://artes.annales.umcs.pl

Data: 26/04/2023 12:35:07

Zapominany instrument, zapomniana praktyka. Tromba marina...

Tabela 1. Klasztory, w których kultywowano grę na tromba marina ${ }^{31}$.

\begin{tabular}{|c|c|c|c|}
\hline Lp. & Kraj/Region & Miejscowość & Klasztory \\
\hline 1 & Austria & Innsbruck & serwitki \\
\hline 2 & & Kremsmünster & benedyktyni \\
\hline 3 & & $\begin{array}{l}\text { Salzburg } \\
\text { Nonnberg } \\
\end{array}$ & benedyktynki \\
\hline 4 & & Salzburg & urszulanki \\
\hline 5 & & $\begin{array}{l}\text { Wiedeń } \\
\text { St. Jakob }\end{array}$ & augustianki \\
\hline 6 & Czechy & Osek & cystersi \\
\hline 7 & Niemcy / Bawaria & $\begin{array}{l}\text { Bad Toelz } \\
\text { Dietramszell }\end{array}$ & augustianie \\
\hline 8 & & $\begin{array}{l}\text { Chiemsee } \\
\text { Fraueninsel }\end{array}$ & benedyktynki \\
\hline 9 & & $\begin{array}{l}\text { Landshut } \\
\text { Seligenthal }\end{array}$ & cysterki \\
\hline 10 & & Wittichen & klaryski \\
\hline 11 & & Toelz Reutberg & franciszkanki \\
\hline \multirow[t]{2}{*}{12} & $\begin{array}{l}\text { Niemcy / Saksonia / Górne Łu- } \\
\text { życe }\end{array}$ & Camenz Mariastern & cysterki \\
\hline & & $\begin{array}{l}\text { St. Marienthal an } \\
\text { der Neisse }\end{array}$ & cysterki \\
\hline 13 & Polska & Kraków & jezuici \\
\hline 14 & & Obra & cystersi \\
\hline 15 & & Sandomierz & benedyktynki \\
\hline 16 & & Stary Sącz & klaryski \\
\hline 17 & Szwajcaria & $\begin{array}{l}\text { Altdorf } \\
\text { St. Karl }\end{array}$ & kapucynki \\
\hline
\end{tabular}

trombae marinae. Opisanie kościola Parafialnego Oberskiego, APO, Akta dotyczace się dezygnacji majątku kościelnego i proboszczowskiego, wikariuszowskiego wraz z instrukcją, b. sygn., cyt. [za:] P. Frasz, Kultura muzyczna w klasztorze cystersów w Obrze do kasaty (1836), praca magisterska napisana pod kierunkiem dr hab. Aliny Mądry w Katedrze Muzykologii UAM, Poznań 2015, s. 30.

${ }^{31} \mathrm{~W}$ tabeli opieram się głównie na danych z pracy Adkinsa i Dickinson (Adkins, Dickinson, op. cit., s. 66), ośrodki dodane przez autorkę artykułu zaznaczone są pogrubieniem. 
Pobrane z czasopisma Annales L - Artes http://artes.annales.umcs.pl

Data: 26/04/2023 12:35:07

Magdalena Walter-Mazur

\begin{tabular}{|l|l|l|l|}
\hline 18 & & $\begin{array}{l}\text { Diessenhoffen } \\
\text { St. Katharinenthal }\end{array}$ & dominikanki \\
\hline 19 & & $\begin{array}{l}\text { Eschenbach } \\
\text { St. Katharina }\end{array}$ & cysterki \\
\hline 20 & $\begin{array}{l}\text { Luzern } \\
\text { St. Anna im Bruch }\end{array}$ & kapucynki \\
\hline 21 & $\begin{array}{l}\text { Luzern } \\
\text { Engelberg }\end{array}$ & benedyktyni \\
\hline 22 & & $\begin{array}{l}\text { Sarnen } \\
\text { St. Andreas }\end{array}$ & benedyktynki \\
\hline 23 & & $\begin{array}{l}\text { Seedorf } \\
\text { St. Lazarus }\end{array}$ & benedyktynki \\
\hline 24 & & $\begin{array}{l}\text { Stans } \\
\text { St. Klara }\end{array}$ & kapucynki \\
\hline 25 & & $\begin{array}{l}\text { Teufen } \\
\text { Wonnenstein }\end{array}$ & kapucynki \\
\hline 26 & & $\begin{array}{l}\text { Wesen } \\
\text { Maria Zuflucht }\end{array}$ & dominikanki \\
\hline 27 & Ukraina & Lwów & benedyktynki \\
\hline
\end{tabular}

Co do Lwowa i Starego Sącza posiadamy jedynie wzmianki o wykorzystywaniu tromba marina, która w Rzeczypospolitej była nazywana tubą, od jej latynizowanej nazwy tuba marina ${ }^{33}$. I tak, w Starym Sączu ksieni Konstancja Jordanówna w 1692 roku powołała do życia świecką kapelę klasztorną, która działała aż do kasaty klasztoru w roku $1782^{34}$. Zaraz po objęciu urzędu, w 1691 roku, ksieni zaangażowała muzyka, który miał za zadanie uczyć siostry gry na „tubie i basie”35.

${ }^{32} \mathrm{~W}$ tym klasztorze zachowały się kompozycje wokalno-instrumentalne Wolfganga Ittena z partiami przeznaczonymi na tromba marina: dwie arie z 1751 roku (RISM 400004604) oraz pastorella z 1738 (RISM 400004569). Poza tym, w bazie danych RISM znajdują się jeszcze tylko dwa utwory kościelne z trombae marinae w składzie: są to msze Ernesta Eberlina (RISM 659000306) oraz Karla Heinricha Bibera (RISM 659000130), oba rękopisy związane z klasztorem Benedyktynek Nonnberg.

${ }^{33}$ Polski ludowy instrument tubmaryna wywodzi swoją nazwę przypuszczalnie właśnie od tej stosowanej na ziemiach polskich dla interesującego nas instrumentu.

${ }^{34} \mathrm{~W} 1811$ roku kasatę odwołano.

${ }^{35}$ Por.: Walter-Mazur, op. cit., s. 281. 
Dodać należy, że od 1673 roku w regestrach rozchodów pojawiają się raz lub dwa razy do roku kwoty przeznaczane na zakup ,strun do chóru”. Z tego samego źródła dowiadujemy się, że klasztor posiadał skrzypce dyszkantowe i basowe - zapewne wiolonczelę, dwoje skrzypiec tenorowych i jeszcze jedne bliżej nieokreślone. Tuba (tromba marina) pojawia się w rejestrze instrumentów należących do świeckiej kapeli spisanym w roku 1704, obok fagotu, kwart puzonu, dwóch trąb, kornetu, sztortu, pary kotłów i dwóch faifar (prawdopodobnie flety lub oboje) ${ }^{36}$.

Fakt, że w regestrach klasztornych nie ma mowy o zakupie tromba marina i że tylko jeden taki instrument znajdował się w roku 1704 „,na stanie” świeckiej kapeli, wolno nam interpretować dwojako. Można uznać, że skoro siostrom opłacono nauczyciela gry na instrumencie, to zapewne taki instrument lub instrumenty były do dyspozycji i zakonnice na nim grały, a brak ich odnotowania wynika z niekompletnie zachowanych źródeł. Można jednak postawić i taką hipotezę, iż w momencie powstania kapeli, w której skład wchodziły trąbki, gra na tromba marina przestała być zakonnicom potrzebna. Działania ksieni Jordanówny dobitnie wskazują na to, że chciała ona doprowadzić do ukonstytuowania w klasztorze aktualnej praktyki muzycznej obejmującej wykonania wokalno-instrumentalne. Źródła wskazują, że śpiew i grę na instrumentach smyczkowych siostry „wzięły na siebie", organista świecki był zatrudniany stale już od dawna, a resztę składu, czyli instrumenty dęte i kotły, zapewniała utworzona kapela. Dodajmy, że wspólne wykonania zakonnic i świeckich muzyków nie musiały - i przede wszystkim nie mogły - oznaczać łamania klauzury; wystarczyło, że muzycy byli oddzieleni od siebie, przebywając - odpowiednio - na chórze zakonnym i muzycznym.

Z kolei w klasztorze lwowskich benedyktynek w zachowanych regestrach wydatków wielokrotnie są wspomniane zakupy „strun do tub”37. Wiemy, że lwowskie mniszki grały na skrzypcach, a jednym z ich nauczycieli na pewno był Jan Piotr Habermann. Wykorzystanie tromba marina jako substytutu trąbek naturalnych pozwalałoby im rozszerzać obsady wykonywanych utworów poza Kirchentrio ${ }^{38}$.

Najwięcej możemy powiedzieć o praktyce wykorzystywania tuba marina w klasztorze sióstr benedyktynek w Sandomierzu. Oprócz sum przeznaczanych na zakup ,strun do tuby”, jakie odnotowano kilkakrotnie w regestrach, zachowały się cztery rękopisy, w których obsadzie pojawia się interesujący nas instrument.

\footnotetext{
${ }^{36}$ Cempura, op. cit., s. 74.

${ }^{37}$ Regestra przychodów i rozchodów klasztoru lwowskiego, rkp. G 16-19, Archiwum benedyktynek lwowskich w Krzeszowie.

${ }^{38}$ Niestety, z muzykaliów po lwowskich benedyktynkach zachowały się tylko trzy rękopisy przechowywane obecnie w Bibliotece Diecezjalnej w Sandomierzu, żaden z utworów nie ma w obsadzie clarini. Na temat ich praktyki muzycznej zob.: Walter-Mazur, op. cit., s.158-162.
} 
Pobrane z czasopisma Annales L - Artes http://artes.annales.umcs.pl

Data: 26/04/2023 12:35:07

Magdalena Walter-Mazur

Niestety, głosy z partią przeznaczoną dla pierwszej i drugiej tuby zachowały się tylko w dwóch z nich.

Pierwszy chronologicznie rękopis muzyczny potwierdzający funkcjonowanie w klasztorze praktyki substytuowania trąbek przez tromba marina pochodzi z 1700 roku, choć inskrypcja odnosząca się do tub może być późniejsza. Jest to koncert religijny Kazimierza Boczkowskiego Christus resurgens ex mortuis ${ }^{39}$ przeznaczony na dwa soprany, bas, trzy trąbki i organo. Wszystkie głosy, poza głosem clarino 3tio, są zapisane ręką kompozytora. Ów głos trzeciej trąbki zapisany jest ręką skryptorki benedyktynek działającej w I połowie XVIII wieku, Zofii Bratysiewiczównej ${ }^{40}$. Na stronie tytułowej inna, trzecia ręka pozostawiła dopisek „Klaryny na skrzypcach grać trzeba”. Jednak na ostatniej stronie manuskryptu pod partią organo widnieje kolejna inskrypcja: „Tuby wystroić na Delasolre wyżey". Tak więc trąbki mogły być substytuowane zarówno przez skrzypce, jak i przez trombae marinae. Dodanie partii trzeciej trąbki było rzeczą niezbyt typową dla ówczesnych obsad, w których instrumenty przeważnie występowały w parach. Sama partia clarino 3tio też była nietypowa, składała się bowiem tylko z dźwięków dwóch wysokości: $d^{1}$ i $g^{141}$. Być może pomysł dodania owej trzeciej trąbki, a w rzeczywistości tromba marina, nasunął się Zofii Bratysiewiczównie w związku z wykorzystywaniem jej w zespole benedyktynek także w charakterze instrumentu towarzyszącego realizacji basso continuo, a nie tylko zastępującego clarini. To jednak wyłącznie przypuszczenia.

Rękopis utworu Christiana Josepha Rutha, Motetto de S. Gertrudis, zawiera już na karcie tytułowej wskazanie o użyciu ,tuby”, tym razem w charakterze instrumentu solowego, na obsadę składają się bowiem Canto i Bas, dwoje skrzypiec, tuba solo oraz fundamento generali. Niestety, jest to dekomplet zawierający jedynie partie obu skrzypiec i fundamento. Uroczysta dedykacja umieszczona na karcie tytułowej dla benedyktynki Marianny Moszyńskiej świadczy prawdopodobnie o tym, iż była ona jedną z zakonnic, które grały na tromba marina. Rękopis będący autografem Rutha nie jest, niestety, datowany, ale możemy przypuszczać, że powstał około połowy wieku ${ }^{42}$.

\footnotetext{
${ }^{39}$ Biblioteka Diecezjalna w Sandomierzu, sygn. A VII 4/ nr 244.

${ }^{40} \mathrm{Na}$ temat tej ciekawej postaci, prawdopodobnie pochodzącej z rodziny muzyków i pełniącej w klasztorze rolę maestra di cappella, por.: Walter-Mazur, op. cit., s. 317.

${ }^{41}$ Joanna Dąbek w pracy licencjackiej Koncerty kościelne K. Boczkowskiego na tle twórczości polskiej II połowy XVII wieku (powstałej pod kierunkiem dr hab. Aleksandry Patalas w Instytucie Muzykologii UJ, Kraków 2012), sugerując się charakterem tej partii, stwierdziła, iż była ona przeznaczona na kotły. Jednak brak w archiwaliach śladów potwierdzających istnienie w klasztorze praktyki gry na kotłach. Zob.: Walter-Mazur, op. cit., s. 250.

${ }^{42}$ K. J. Ruth, Arie, Motetti, wyd. M. Jochymczyk, Kraków 2012, s. 6-7.
} 


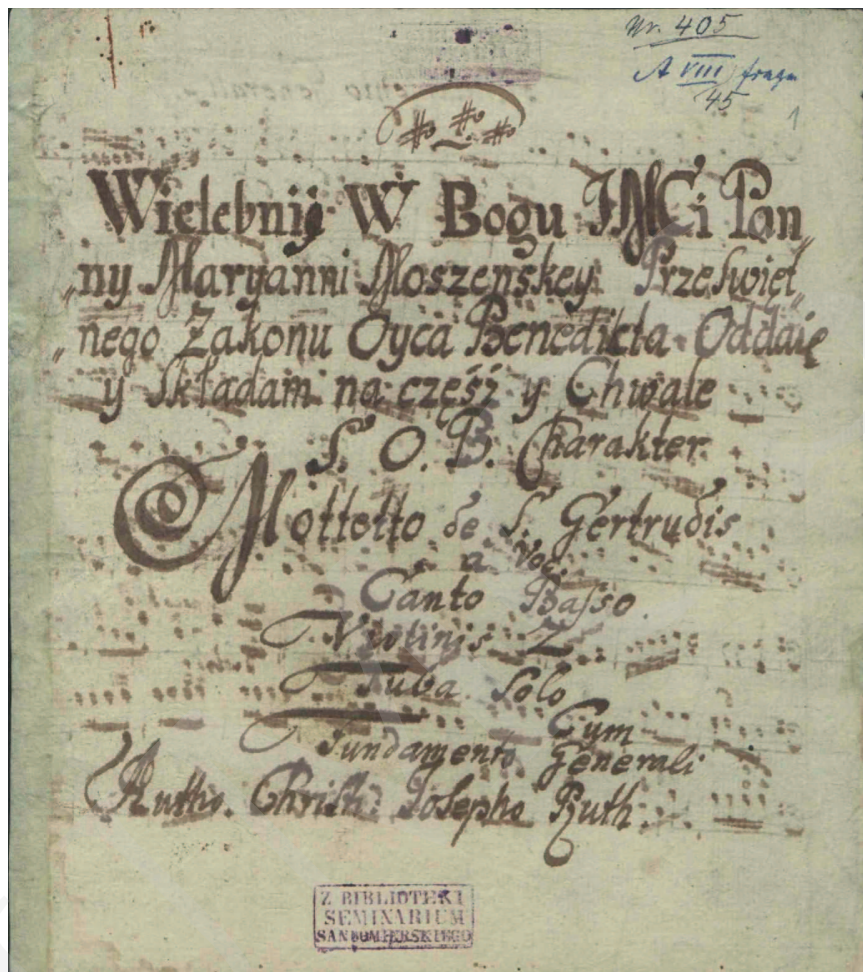

Ilustracja 2. Karta tytułowa rękopisu A VIII 45 / nr 405 Biblioteki Diecezjalnej w Sandomierzu: Christian Joseph Ruth, Motetto de S. Gertrudis, w obsadzie tuba solo.

Najpóźniejszym z rękopisów wskazujących na obecność tromba marina w sandomierskiej kapeli benedyktynek jest przekaz Symfonii in D Johanna Gottlieba Naumanna. Jest to, według mojej dotychczasowej wiedzy, jeden z dwóch rękopisów zachowanych w Polsce zawierających zapis partii trombae marinae ${ }^{43}$. Obsada tej symfonii w sandomierskiej kopii obejmuje pary skrzypiec, obojów, rogów, „tub” oraz organo. Pozostałe przekazy tego utworu, odnotowane w RISM w liczbie ośmiu, mają w swej obsadzie dwie trąbki lub clarini. Cztery z nich ukazują, że mamy tu do czynienia z symfonią-uwerturą do opery Naumanna Solimano, wystawionej w Dreźnie w 1773 roku, później funkcjonującą także samodzielnie w charakterze kameralnego utworu instrumentalnego. Porównanie sandomierskiej kopii symfonii Naumanna z kopią przechowywaną w Biblioteca Civica Angelo Mai w Bergamo ${ }^{44}$ ukazuje, iż partia trąbki niczym nie różni się od tej przeznaczonej dla „tub”.

\footnotetext{
${ }^{43}$ BDS A VI 43 / nr 239.

${ }^{44}$ Autorka dziękuje za uprzejmą pomoc Panu Marcello Eynard z Biblioteca Civica Angelo Mai z Bergamo, który przesłał zdjęcia głosów do porównania.
} 
Pobrane z czasopisma Annales L - Artes http://artes.annales.umcs.pl

Data: 26/04/2023 12:35:07

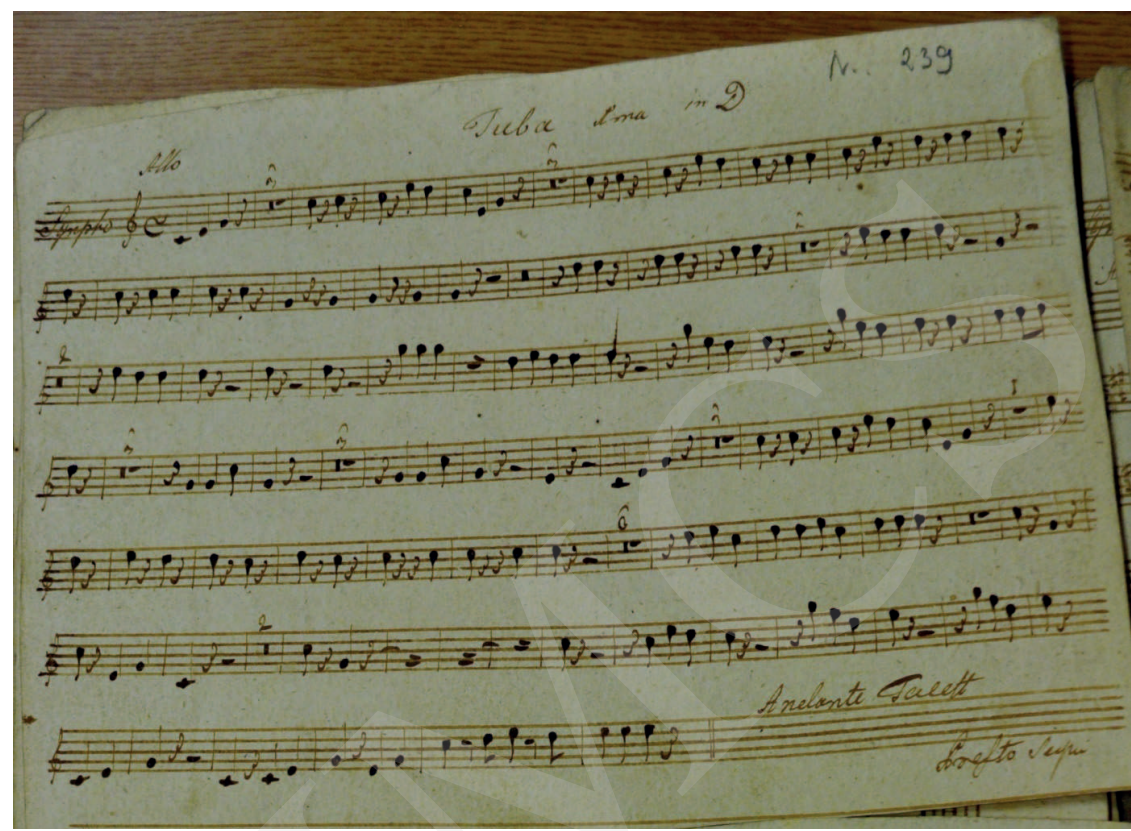

Ilustracja 3. Głos tuba prima z rękopisu A VI 43 / nr 239 Biblioteki Diecezjalnej w Sandomierzu: Johann Gottlieb Naumann, Symfonia in D.

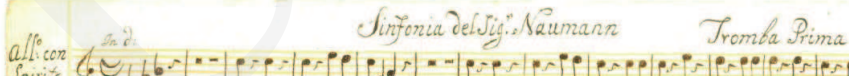

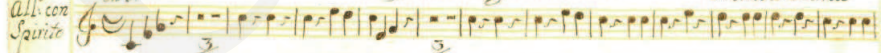

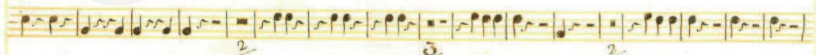

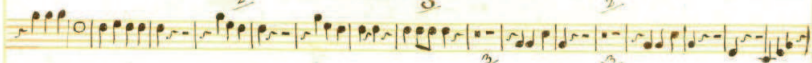

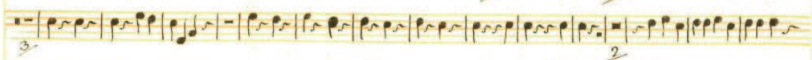

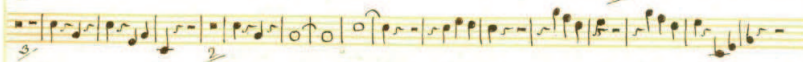

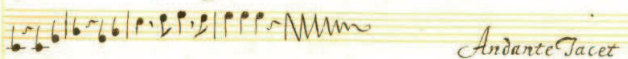

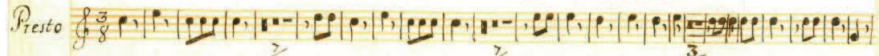

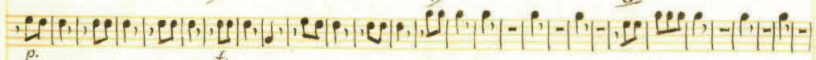

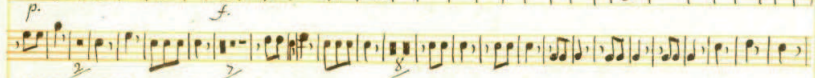

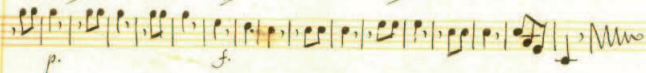

Ilustracja 4. Głos tromba prima z rękopisu Mayr 347.63a Biblioteca Civica Angelo Mai w Bergamo: Johann Gottlieb Naumann, Symfonia in D. 
Drugim - i ostatnim - rękopisem sandomierskim zawierającym partię przeznaczoną dla tromba marina jest pastorella $A$ cóż to się dzieje, datowana na rok 1773, należąca do Marianny Mokronowskiej, jednej z mniszek grających na tym instrumencie. Na okładce instrument określony jest jako tuba pastoralis, głos zatytułowano tuba solo.

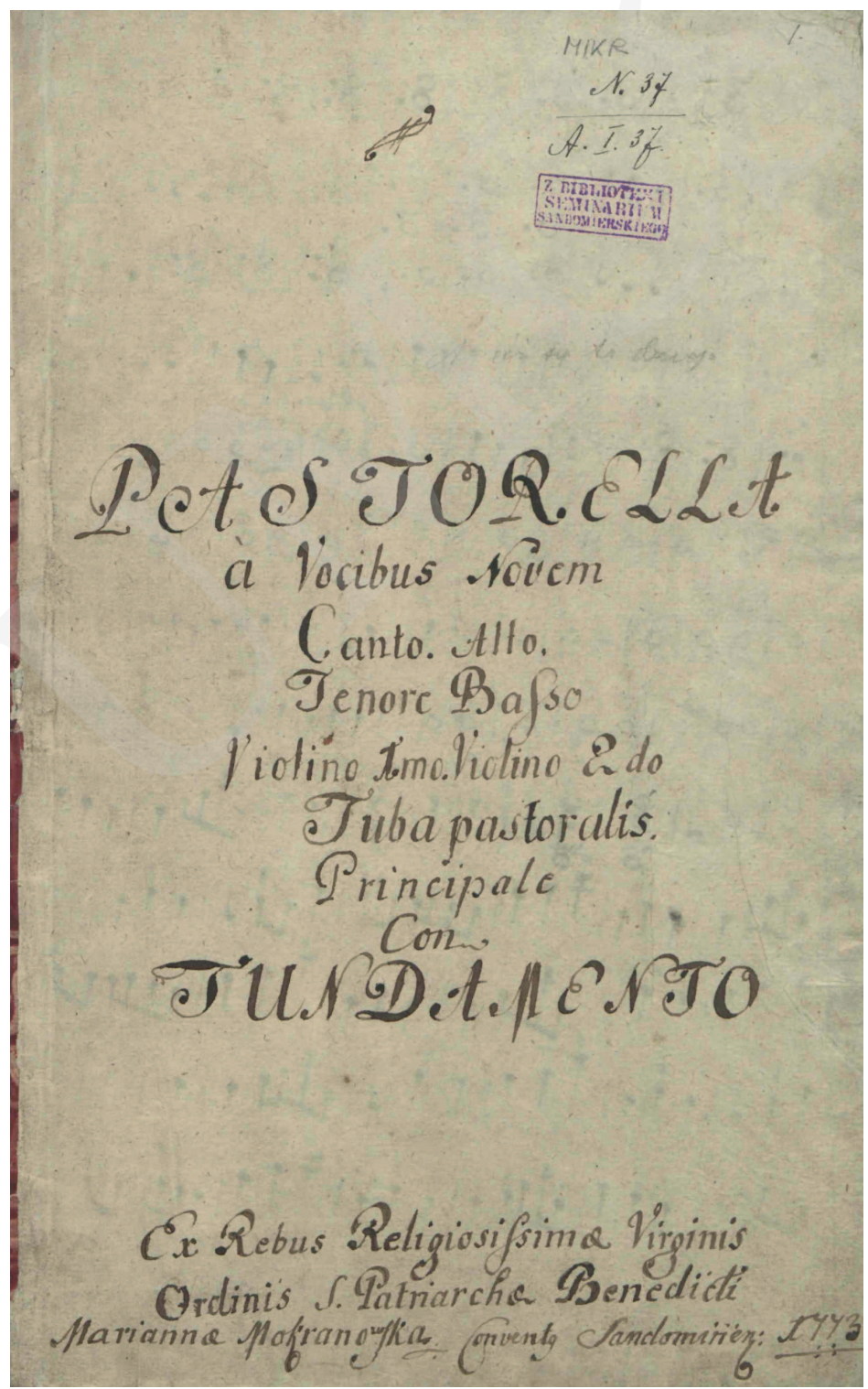

Ilustracja 5. Karta tytułowa rękopisu A I 37 / nr 37 Biblioteki Diecezjalnej w Sandomierzu: Pastorella A cóż to się dzieje (1773), w obsadzie tuba pastoralis. 


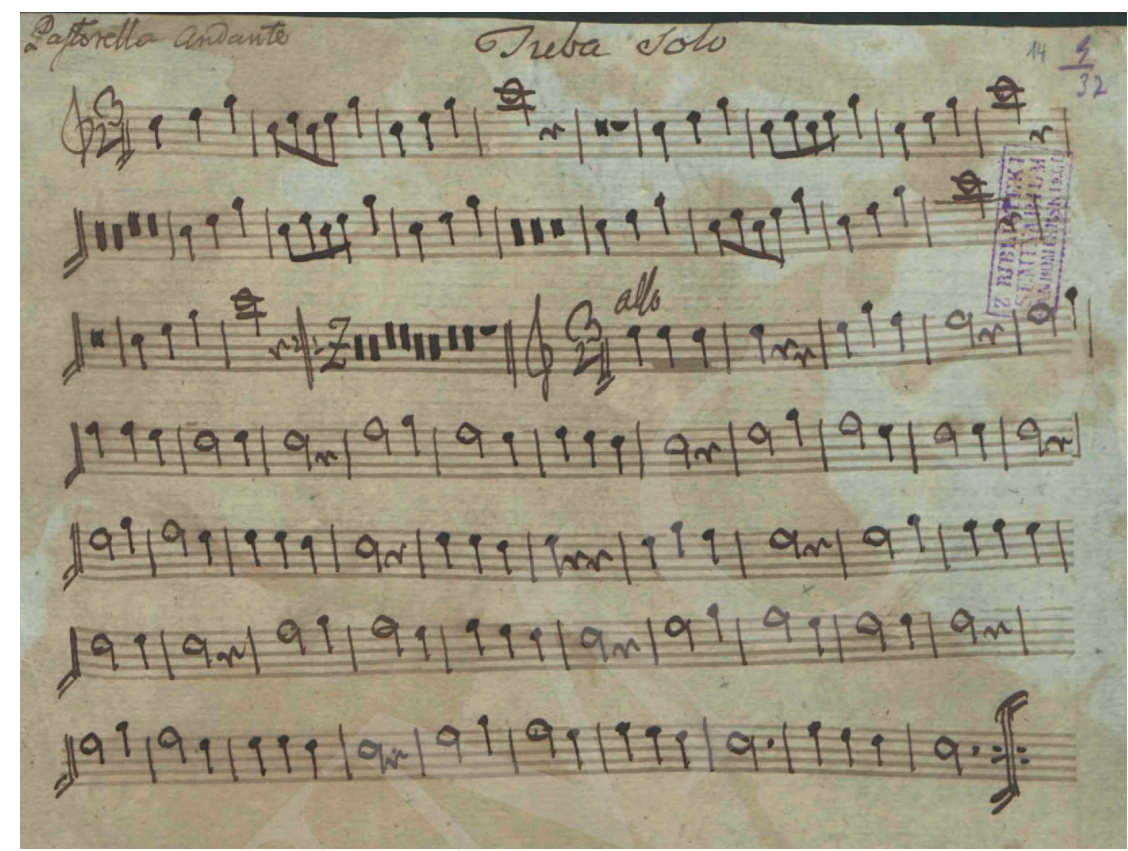

Ilustracja 6. Głos tuba solo z rękopisu A I 37 / nr 37 Biblioteki Diecezjalnej w Sandomierzu: Pastorella A cóż to się dzieje (1773).

Trudno powiedzieć, w jakim wymiarze praktyka gry na Nonnengeige współtworzyła kulturę muzyczną sandomierskiego klasztoru i na ile była w niej istotna. Łatwiej określić, w jakim okresie była kultywowana. Rękopisy wskazujące na udział trombae marinae w wykonaniach pojawiają się w od roku 1700 do lat siedemdziesiątych XVIII wieku. W nekrologach zakonnic w przypadku trzech odnotowano, iż grały ,na tubie"; były to: Anna Stogniewowna (ok. 1685-1771), Łucja Czeladzińska (ok. 1688-1770) i Elżbieta Dutkiewiczówna (ok. 1760-1794). Prawdopodobnie grały na tym instrumencie także Zofia Bratysiewiczówna (ok. 1673-1730), Marianna Moszyńska (ok. 1715-1782) i Marianna Mokronowska (ok. 1754-1802), o czym wnosimy na podstawie zachowanych i omówionych wyżej rękopisów. Jest możliwe, że i dwie inne mniszki, o których w nekrologach zapisano, iż grały na różnych instrumentach - Cecylia Zygmuntowska (ok. 1726-178945) i Agnieszka Sosnowska (ok. 1755-1827), potrafiły w zespole substytuować partie clarini, grając na tromba marina. Wśród stu trzydziestu utworów wokalno-instrumentalnych i kameralnych trąbki znajdujemy w obsadzie

${ }^{45}$ Jako muzyk aktywna w klasztorze sandomierskim w latach 1743-1765. Z powodu konfliktów przeniosła się do Radomia, do Sandomierza wróciła kilka lat przed śmiercią. Zob.: Walter-Mazur, op. cit., s. 194-196, 198-200, 207-208. 
trzydziestu siedmiu. Trzeba jednak przypomnieć, że benedyktynki mogły zastępować partie trąbek także grając na skrzypcach, oraz wspomnieć o jeszcze innej możliwości, która jest poświadczona dla lat 1769-1791, mianowicie o opłacaniu muzyków z innych kapel, którzy brali udział - przy zachowaniu klauzury - w wykonaniach klasztornej kapeli ${ }^{46}$. W regestrach wydatków, które zachowały się dla lat 1739-1806, w każdym roku spotykamy sumy wydatkowane na zakup „strun do choru”, jednak w latach 1787, 1790 i 1792 podskarbianka zapisuje wyraźnie sumy „za strony do Tuby na chor”, przy czym nie wiemy, czy jest to dowodem intensywnego użytkowania instrumentów, czy wynikiem jej skrupulatności ${ }^{47}$. W inwentarzu z 1816 roku sporządzonym na polecenie Centralnych Władz Wyznaniowych w Królestwie Polskim wymieniono obok fortepiano i dwojga skrzypiec „starych” dwa „turubany bez stron” 48 - wprawdzie jest to nazwa, której nie zna nawet Adkins, lecz do jakiego innego instrumentu mogłaby należeć, jeśli nie do tuba marina? Reasumując, można śmiało stwierdzić, że praktyka gry na Nonnengeige występowała u sandomierskich zakonnic na przestrzeni całego XVIII stulecia i zanikła wraz z przemianami ich kultury muzycznej, które dokonały się na przełomie XVIII i XIX wieku'9

$\mathrm{Na}$ koniec nasuwa się jeszcze jedno pytanie. Co spowodowało, że tromba marina, instrument dość kuriozalny, który nie znalazł swego miejsca w profesjonalnym muzykowaniu w XVIII wieku, nie mówiąc już o czasach późniejszych, zyskał taką popularność w żeńskich środowiskach zakonnych Europy Środkowej?

${ }^{46}$ Są to liczne wpisy w rodzaju: „Trębaczom na S[więty] O[jciec] Benedykt”, „Trębaczom na S[więty] Michał". Jeden z trębaczy, Chęciński, jest odnotowany z nazwiska. Chór zakonny w sandomierskim kościele św. Michała należącym do benedyktynek był przedzielony kratą na dwie części. Jedna część chóru była połączona z korytarzem klauzury, do drugiej - tej dla muzyków - wchodzono z kościoła po schodkach.

${ }^{47}$ Regestra podskarbskie zaczynające się w R.P. 1769, rkp. G 889 Biblioteki Diecezjalnej w Sandomierzu, bez paginacji.

${ }^{48}$ Cyt. [za:] W. Łyjak, Przyczynki do dziejów muzyki u Panien Benedyktynek $w$ Sandomierzu, „Ruch Muzyczny” 1983, nr 16, s. 26. Pierwszą myślą piszącej te słowa, zwerbalizowaną w książce Figura i fraktem... (zob.: Walter-Mazur, op. cit., s. 148), było skojarzenie z teorbanem. Jednak są powody, dla których obecność dwóch teorbanów w inwentarzu z 1816 roku wydaje się mało prawdopodobna. Po pierwsze, nigdzie $w$ archiwaliach po benedyktynkach nie ma żadnej wzmianki ani żadnego dowodu posiadania i używania przez mniszki teorby lub też teorbanu; po drugie, instrumenty tego typu, używane do akompaniowania, raczej nie występowały w parach, wystarczyłby więc jeden. Z kolei argumentem za przyjęciem tej hipotezy byłaby popularność teorbanu jako instrumentu akompaniującego w muzyce świeckiej na polskich dworach w XVIII wieku.

${ }^{49}$ Por.: M. Walter-Mazur, Przemiany praktyki muzycznej benedyktynek sandomierskich $w$ drugiej połowie XVIII i w XIX wieku, [w:] Księga pokonferencyjna z Międzynarodowej Konferencji „,Klasztor w nowej rzeczywistości. Koniec XVIII-początek XX wieku”, Pelplin, 15-18 września 2016 (w przygotowaniu do druku). 
Pobrane z czasopisma Annales L - Artes http://artes.annales.umcs.pl

Data: 26/04/2023 12:35:07

Magdalena Walter-Mazur

Adkins i Dickinson uważają, iż było to wynikiem zaostrzenia rygoru w klasztorach żeńskich po soborze trydenckim. Poza zwróceniem uwagi na ścisłą klauzurę, wielu biskupów, pod których obediencją znajdowały się mniszki, szczególnie w krajach oddalonych od Rzymu, zakazywało używania instrumentów innych niż organy jako pomocy przy odprawianiu liturgii śpiewem ${ }^{50}$. W związku z rozpowszechnieniem się po 1600 roku praktyki basso continuo zapewne nie widziano problemu w dołączeniu do organów tuba marina jako instrumentu fundamentalnego ${ }^{51}$. Ograniczenia dotyczące praktyki muzycznej stopniowo ulegały rozluźnieniu, a w związku z aktualnym stylem muzycznym, w którym ważną rolę pełniły instrumenty obligato, zaczęto stosować posiadane trombae marinae jako substytuty clarini. Ponadto, wiadomo, że w niektórych klasztorach wykonywano na nich także fanfary z towarzyszeniem kotłów ${ }^{52}$. Prawdopodobnie więc wielość zastosowań także przyczyniła się do popularności trombae marinae. Adkins i Dickinson zauważają także, że gra na tym instrumencie była stosunkowo łatwa do opanowania; możemy dodać, że prawdopodobnie w związku z tym starsze instrumentalistki uczyły młodsze adeptki i nie było potrzeby zatrudniania do tego nauczycieli z zewnątrz, co często miało miejsce w przypadku gry na innych instrumentach. Mimo wszystko jednak zastanawiające jest, dlaczego zakonnice tak rzadko próbowały grać na trąbkach, skoro wiadomo, że grywały na waltorniach ${ }^{53}$. Prawdopodobnie utrzymywanie praktyki grania na ,tubach” miało związek z kultywowaniem wewnętrznych tradycji w poszczególnych klasztorach; przywiązanie do własnych zwyczajów i świadomość przekazywania tradycji są widoczne chociażby na kartach zwyczajników i ceremoniarzy klasztornych ${ }^{54}$.

Praktyka substytuowania trąbek przez tromba marina, spotykana w wielu ośrodkach klasztornych Europy Środkowej, według wiedzy autorki, stała się inspiracją dla jednego tylko zespołu spośród tak licznych obecnie grup wykonujących

\footnotetext{
${ }^{50}$ Rzeczywiście, w regułach polskich benedyktynek, wydawanych w I połowie XVII wieku, znajdowały się uwagi o zakazie używania instrumentów. Por. S. Dąbek, Problematyka muzyczna w najstarszych redakcjach regut benedyktynek w języku polskim, „Barok” 1997, nr 2, s. 62-74, M. Borkowska, Życie codzienne polskich klasztorów żeńskich w XVII-XVIII wieku, Warszawa 1996, s. 290.

${ }^{51}$ Adkins, Dickinson, op. cit., s. 67.

${ }^{52}$ Najwięcej o praktyce wykorzystywania tromba marina wiadomo w odniesieniu do klasztoru benedyktynek Nonnberg w Salzburgu. Zob.: G. Walterskirchen, "Musica figuralis est in bono statu". Musik im Benedictinen-Frauenstift Nonnberg in Salzburg, [w:] Musik der geistlichen Orden in Mitteleuropa zwischen Tridentinum und Josephinismus, red. L. Kačic, Bratysława 1997, s. 25-34 oraz Koldau, op. cit., s. 691-695.

${ }^{53}$ Jedyną znaną polską zakonnicą, o której wiadomo, że uczyła się grać na waltorni, była sandomierska benedyktynka, Elżbieta Dutkiewiczówna. Na trąbkach grały na przykład urszulanki z Bratysławy (dawniej Pressburg), zob.: ibid., s. 873.

${ }^{54}$ Por. na przykład rękopis D4 Archiwum benedyktynek lwowskich w Krzeszowie.
} 
muzykę dawną. Łatwiej znaleźć w internecie nagrania i inne dowody współczesnego wykorzystania tego instrumentu przez zespoły grające „muzykę korzeni”, łączącą wyobrażenia o muzyce średniowiecznej z elementami zachowanej tradycji oralnej, jakkolwiek często wykonawcy ci posługują się trombae marinae w jej XVII-wiecznej, „długiej” i opartej na ziemi postaci. Jedynym zespołem, który odwołał się do zapomnianej praktyki wykorzystania Nonnengeige w muzyce wokalno-instrumentalnej XVII i XVIII wieku, jest założony w 1991 roku w Bazylei przez Thilo Hirscha Ensemble Arcimboldo. Zespół w 2005 roku wydał płytę będącą zwieńczeniem projektu „Musik aus Schweizer Klöstern mit Tromba Marina" ${ }^{55}$. Efekt dźwiękowy jest bardzo ciekawy i całkowicie satysfakcjonujący ${ }^{56}$. Po wysłuchaniu utworów z trombae marinae w obsadzie przestaje dziwić popularność tego instrumentu w klasztornych kapelach i zupełnie przestaje śmieszyć uwaga molierowskiego Monsieur Jourdaina.

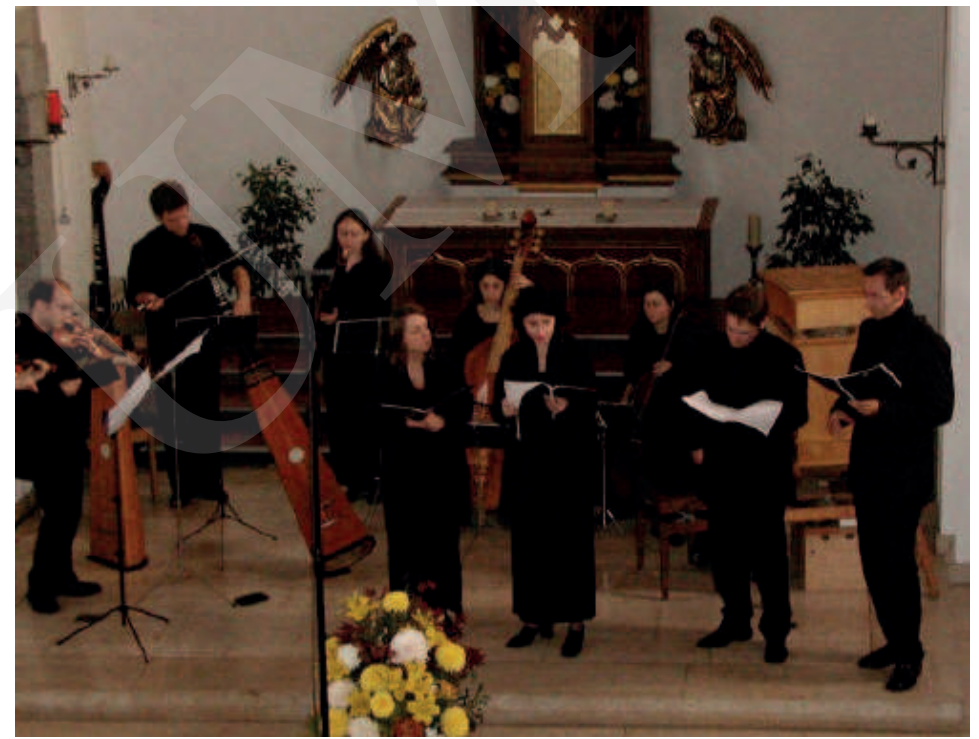

Ilustracja 7. Ensemble Arcimboldo, koncert w ramach projektu „Musik aus schweitzer Klöstern mit Tromba Marina”, fot. P. Bürgisser.

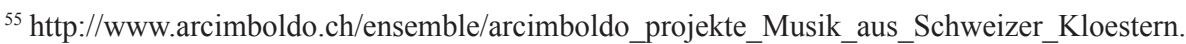
htm MGB CD 6224 musiques suisses [data dostępu: 06.02.2017].

${ }^{56}$ Thilo Hirsch w książeczce towarzyszącej płycie pisze o swoich doświadczeniach w grze na tromba marina. Zauważył on mianowicie, że „nieczystości” górnych tonów harmonicznych można korygować mocniejszym naciskiem kciuka na strunę i jest to łatwiejsze niż korygowanie ich ustami na trąbce naturalnej. Hirsch uważa, że do opanowania gry na tromba marina, w stopniu pozwalającym na udział w wykonaniach podczas liturgii, wystarczył rok lub dwa nauki, podczas gdy trąbka naturalna wymagała czterech lub pięciu lat. Zob.: http://www.arcimboldo.ch/ensemble/arcimboldo_ projekte_Musik_aus_Schweizer_Kloestern.htm\#Besetzung [data dostępu:02.06.2017]. 


\section{SUMMARY}

Tromba marina (trumpet marine) - the instrument originated from the monochord and known from the Middle Ages - was not widely used in professional music. That special chordophone had, however, its day in French music about the mid-seventeenth century. In 1660 Jean Baptiste Lully used trombae marinae in ballet sections of Francesco Cavalli's opera Xerxes, and in 1661, at the court of Louis XIV a group of five musicians was formed, who played crumhorns and trombae marinae. The only virtuoso of this instrument, known by name, was Jean Baptiste Prin (ca. 1699-1742), who made a collection of 216 pieces for trumpet marine (tromba marina).

Out of the many names of the instrument (tuba marina, tuba maritima, Trumscheit, Marientrompette), the historically latest names are the nineteenth-century ones showing that it was used by nuns. There are three names in German, based on the compounds Nonne (nun) with the name of the instrument or with designation of its function in a musical group: Nonnengeige, Nonnentrompette, and Nonnenbas, which would prove that nuns still played the trombae marinae in the German-speaking area as late as in the nineteenth century.

Cecil Adkins and Alis Dickinson, the authors of the monograph devoted to tromba marina, listed 29 monastic centers (of which 26 were nuns' convents), in which the playing of Nonnengeige was cultivated, and come to the conclusion that in the eighteenth century this was the specialty of Central European nuns. We can add some more names to those recorded by the two authors: the St. Jakob Augustinian nunnery in Vienna, the Servite Nunnery in Innsbruck, and three convents in the German-speaking part of Switzerland. Furthermore, we can also broaden the geographical range of the practice of playing tromba marina towards North-East because we have evidence that it was cultivated in the convents of Benedictine nuns of Sandomierz and Lvov, the convent of St. Clare in Stary Sącz, as well as in the Jesuit chapel in Krakow.

The instrument in question exercised different functions in the performing practice in monasteries: it was used in the practice of chorale singing, it served as a fundamental instrument in the basso continuo section, it appeared as a substitute for trumpets in the vocal-instrumental forces, finally - as part of a group consisting of three or four trombae marinae and kettledrums, it played fanfares. 